\title{
Mucosa-Associated Lymphoid Tissue Lymphoma Arising from the Ethmoid Sinus Mucosa: A Case Report and Review of the Literature
}

\author{
Young Woo Lee ${ }^{1}$, Young Min Moon ${ }^{1}$, Seok Joo Lee ${ }^{2}$, and Hyung-Ju Cho ${ }^{1,3} \mathbb{C}$ \\ ${ }^{1}$ Departments of Otorhinolaryngology, ${ }^{2}$ Pathology, ${ }^{3}$ The Airway Mucus Institute, Yonsei University College of Medicine, Seoul, Korea
}

사골동에 발생한 점막연관림프조직 림프종 1 예

이영우 ${ }^{1} \cdot$ 문영민 $^{1} \cdot$ 이석주 ${ }^{2} \cdot$ 조형주 ${ }^{1,3}$

연세대학교 의과대학 이비인후과학교실, ${ }^{1}$ 병리학교실, ${ }^{2}$ 기도점액연구소 ${ }^{3}$

\author{
Received March 28, 2019 \\ Revised July 11, 2019 \\ Accepted August 7, 2019 \\ Address for correspondence \\ Hyung-Ju Cho, MD, PhD \\ Department of Otorhinolaryngology, \\ Yonsei University \\ College of Medicine, \\ 50-1 Yonsei-ro, Seodaemun-gu, \\ Seoul 03722, Korea \\ Tel $+82-2-2228-3605$ \\ Fax $+82-2-393-0580$ \\ E-mail hyungjucho@yuhs.ac
}

\begin{abstract}
Most of nasal cavity or paranasal sinuses lymphoma reported in Korea is either diffuse large Bcell lymphoma or natural killer/T-cell lymphoma. There are only three cases of mucosa-associated lymphoid tissue lymphoma (MALTOMA), which has so far been reported only in a Korea journal and all of which have occurred in the nasal cavity and in the turbinate. We experienced a case of MALTOMA of ethmoid sinus extending to the orbital cavity. It was confirmed by the findings of immunohistochemical staining (positive with CD20, Bcl-2, and Granzyme B, negative with CD5, CD56, Bcl-6 and Cyclin D1). The patient underwent radiation therapy and the lesion was successfully resolved without recurrence for 16 months.
\end{abstract}

Korean J Otorhinolaryngol-Head Neck Surg 2020;63(7):319-23

Key Words B-cell · Lymphoma $\cdot$ Mucosa-associated lymphoid tissue $\cdot$ Paranasal.

\section{서 론}

림프종은 모든 악성신생물 중 3 5\% 정도 차지하며, 비호지 킨성 림프종은 림프종의 $60 \%$ 를 차지한다. 비부비동에서 발생 하는 비호지킨성 림프종의 경우는 0.2 2\%에 불과하며, ${ }^{1)}$ 대부 분은 미만성 거대 B 세포 림프종(diffuse large B-cell lymphoma, DLBCL)이나 NK/T 세포 림프종[natural killer(NK)/ $\mathrm{T}$-cell lymphoma]이며 점막연관림프조직 림프종[mucosaassociated lymphoid tissue lymphoma(MALTOMA, MALT) 림프종]은 국내에서는 단 3예만 보고되었으며, 모두 하비갑개 및 하비도에 발생한 경우로 부비동에 발생된 사례가 보고된 증례는 없었다. ${ }^{2,3)}$

본 논문에서는 사골동에서 발생하여 안와 내까지 침범하

This is an Open Access article distributed under the terms of the Creative Commons Attribution Non-Commercial License (https://creativecommons.org/licenses/by-nc/4.0) which permits unrestricted non-commercial use, distribution, and reproduction in any medium, provided the original work is properly cited.
여 안구 돌출 증상을 유발한 MALT 림프종을 진단하고 치료 한 증례를 문헌고찰과 함께 보고하는 바이다.

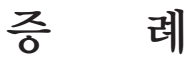

1달 전부터 발생한 우측 안구 돌출을 주소로 내원한 34세 남자 환자로 본원 안과 내원 및 시행한 안면 computed to$\operatorname{mography}(\mathrm{CT})$ 검사에서 비강 내 종물이 확인되어 의뢰되었 다. 환자는 과거력 및 가족력상 특이사항은 없었으며, 안구 돌 출 및 경미한 유루증과 결막 충혈 외에, 안구운동 제한 및 통 증을 호소하지는 않았으며 경도의 코막힘 이외에는 특별한 증상을 호소하지 않았다. 비강의 진찰 소견상 경도의 우측 비 중격 편위 소견 외에는 조직검사를 시행할 수 있는 종괴가 확 인되지는 않았다. 수술 전 재시행한 부비동 CT상 우측 비강 의 사골포를 포함한 전사골동 및 후사골동과 사골 안와판을 침범하여 안와 내까지 침범되어 있는 조영증강되어 있는 종괴 
소견을 확인할 수 있었으며(Fig. 1) magnetic resonance im$\operatorname{aging}(\mathrm{MRI})$ 검사에서 고강도로 조영증강되는 종괴 소견을 확 인할 수 있었다(Fig. 2).

영상검사로 병변에 대한 진단이 불충분하였으므로 병변에 대한 정확한 진단을 하기 위해 조직검사를 계획하였으며, 외 래에서 내시경 소견 하에 병변이 관찰되지 않았기 때문에 병 변을 확실히 노출하고 조직을 충분히 확보하기 위해 검사는 전신마취 하에 진행되었다. 내시경 유도하 구상돌기 절제술 과 전방 사골동 절제술을 시행한 후 사골동에서 종물을 관찰 하였다(Fig. 3). 종물은 사골동을 채우고 있었으며, 사골안와 판의 결손과 함께 안와 내측으로 연결되어 확장되어 있었다. 종괴는 경계가 사골동 내 점막과 비교적 용이하게 구분되었으 며, 성상은 일반적으로 관찰되는 반전성 유두종과 유사하였다.
수술 중 일부 조직에서 시행한 동결절편검사상 저분화성 $\mathrm{B}$ 세 포 림프종 소견이 보고되었다. 사골동 부위의 종물은 출혈이 적고 주변 조직과 박리가 용이하여 안와 내 부위의 종물을 제 외하고 사골동 내 종물은 육안적으로 구분이 가능한 부분은 우선 제거 후, 잔존암에 대해서는 조직검사 결과에 따라 항암 또는 방사선 요법시행 등을 계획하며 수술을 종료하였다. 최 종 병리조직검사 결과 점막 주변의 미만성 림프구 침윤 소견이 확인되었으며 면역 조직 화학검사상 CD20, Bcl-2, Granzyme $\mathrm{B}$ 양성 및 $\mathrm{CD} 5, \mathrm{CD} 56, \mathrm{Bcl}-6$ 및 Cyclin D1 음성 소견 보여 MALT 림프종으로 진단되었다(Fig. 4).

환자의 병기를 설정하기 위한 골수검사, 흥부 및 복부 CT 검사와 positron emission tomography-CT(PET-CT) 검사 상 원발병소인 우측 비강 및 추가병소인 우측 안와 내의 병변
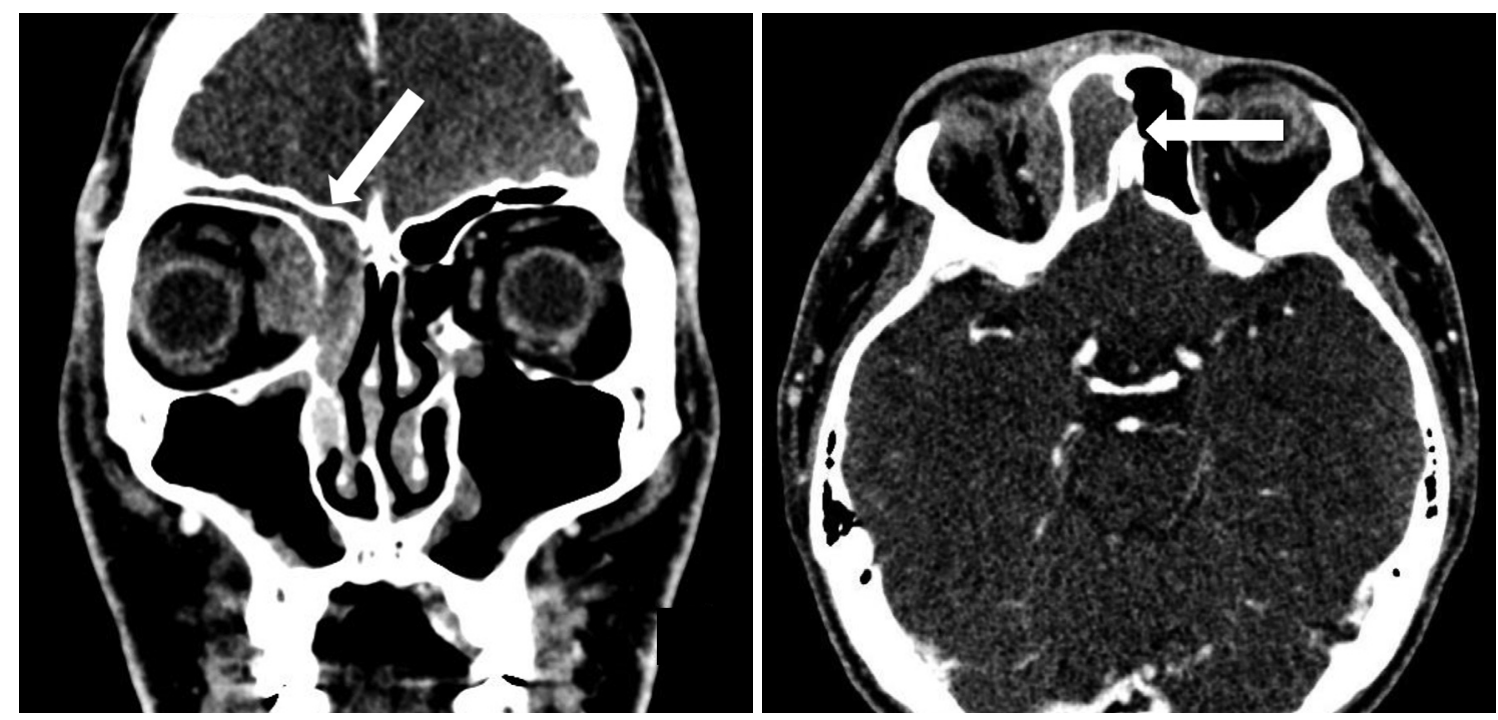

Fig. 1. Pre-operative paranasal computed tomography (contrast) coronal and axial views of lymphoma patient. The white arrows (both view) indicates homogenous small mass in right nasal cavity and orbit cavity.
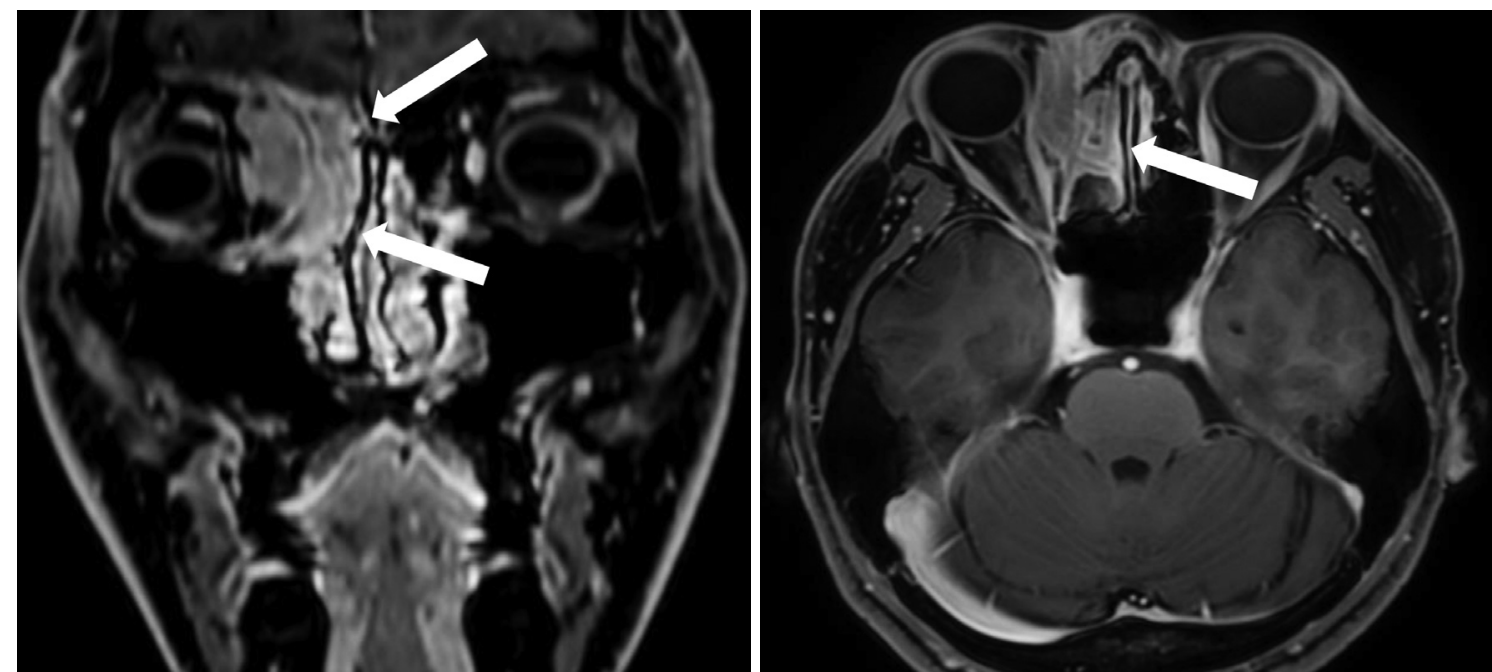

Fig. 2. Pre-operative paranasal magnetic resonance imaging (T1-gadolinium enhanced coronal and axial views) of lymphoma patient. The white arrows (both view) indicates hyperintense soft tissue involving right ethmoid sinus extending into right extraconal space. 
외에 원격 전이 및 골수 전이 소견은 없어서 최종병기는 Stage IIE로 설정할 수 있었다. 안구 내 잔존병변의 치료를 위해 본 원 혈액내과 및 방사선 종양학과에 의뢰하여 3주간 총 14회, 총 방사선량 $2520 \mathrm{cGy}$ 의 치료적 방사선 요법(therapeutic radiotherapy)을 시행하였다. 현재까지 16개월 추적관찰상 안구 증상 및 비강 내 종물 소견 모두 호전되었으며 16개월째 재 시행한 부비동 CT상 재발 소견 없는 채로(Fig. 5) 추적 관찰 중이다.

\section{고 찰}

비강에 발생한 MALT 림프종은 Shin과 $\mathrm{Lim}^{2}$ 이 2006년 국 내에 처음 보고하였으며 이후 $\mathrm{Kim}$ 등이이 하비갑개 점막에 발 생한 MALT 림프종 2예를 보고한 바가 있다. 그러나 부비동

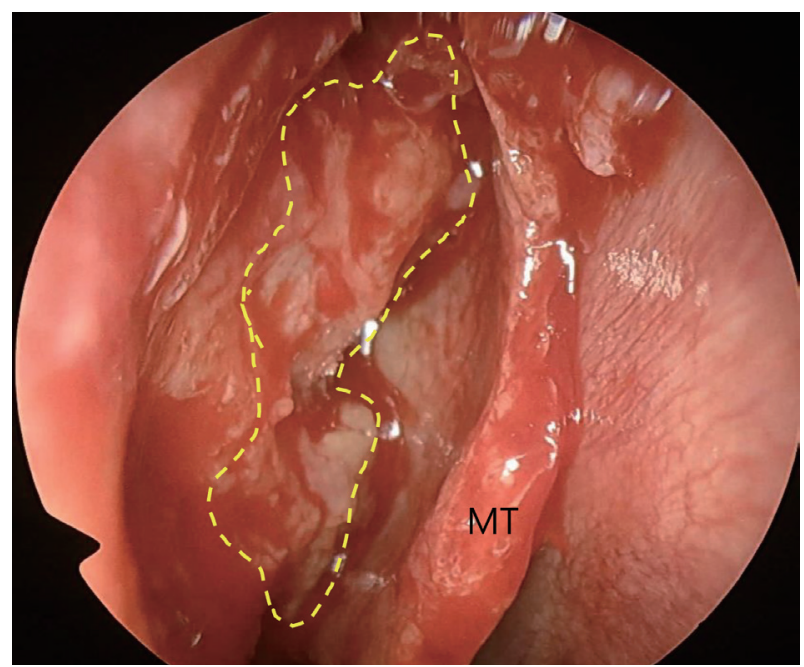

Fig. 3. Endoscopic finding of mass in middle meatus after uncinectomy (dotted line indicates the boundary of mass). MT: middle turbinate.
에 발생된 경우는 아직까지 보고가 없으며 국내에 발생빈도 가 매우 드문 질환으로 사료된다. 본 증례에서는 안와 침범까 지 동반되며 안구 돌출 및 부종 증상으로 인하여 비교적 진 단이 조기에 가능했으나 일반적으로 비강 내 발생한 림프종 의 경우 임상적으로는 비폐색, 비내 종물, 안면부종, 비루 및 비출혈 등 일반적인 만성 부비동염과 증상의 차이가 없어 초 기 치료로 만성 부비동염에 준한 치료를 하다가 진단이 늦어 지는 경우가 있다. ${ }^{4}$ 본 증례에서는 사골동 점막에서 기원한 종양으로 종물이 사골포 후면에 위치하고 있어 수술 전 비강 내시경을 통한 진단의 어려움이 있었다. 수술 전 시행한 CT상 사골 안와판의 골파괴 소견 및 안와 내 종괴 침범, MRI 소견 상 높은 강도의 조영증강이 되는 소견으로 악성 종양을 의심 할 수 있었기 때문에 수술을 통한 조직검사로 MALT 림프종 을 진단하였고, 이후 병기 설정을 위한 PET-CT 등의 검사 후 방사선 치료를 진행하였다.

부비동 및 안와벽을 침범하는 림프종 중 진행성으로 나쁜 예 후를 보이는 비강 내 악성종양 중 $\mathrm{T}$ 세포 기원의 비호지킨성 림 프종이 있으며 이는 반드시 감별하여야 할 질환이다. ${ }^{3)}$ MALT 림프종과의 차이점은 MALT 림프종의 경우 림프상피성(lymphepithelial) 병변이라고 하는 상피조직을 침범하는 경우가 특징적이지만 이는 염증 반응에서도 관찰될 수 있어 면역조 직화학검사를 통해 최종진단을 하게 된다.5) 본 증례의 경우 hematoxylin and eosin 염색상 림프구성 세포의 증식 소견 을(Fig. 4A) 보여 림프조직연관 병변으로 의심되어 면역조직 화학검사를 시행하였다. CD20에 양성 소견을 보이며(Fig. 4B) 조직학적으로 소림프구성 병변을 보이는 경우 $\mathrm{B}$ 세포성 림프 종으로 진단을 하게 되며 여기에는 만성림프모구 백혈병/소림 프구 림프종(chronic lymphoblastic leukemia/small lymphocytic lymphoma, CLL/SLL), 소포성 림프종(follicular
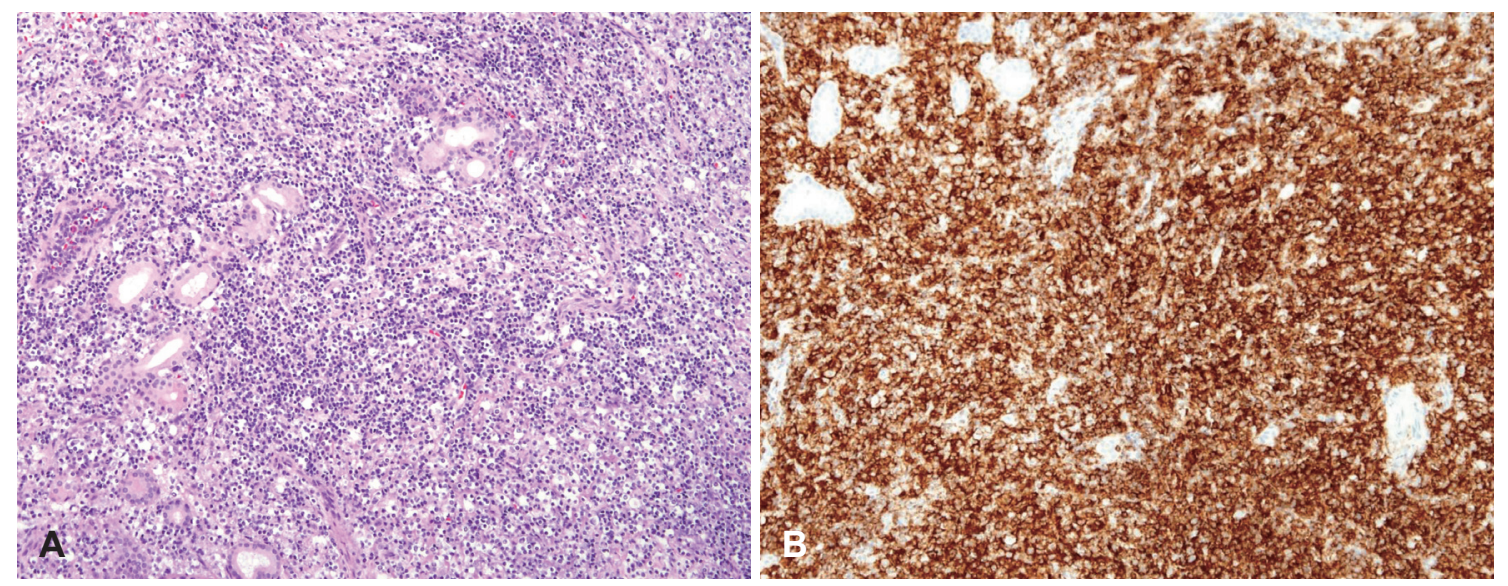

Fig. 4. Histopathologic findings. Dense proliferation of small round to irregular lymphoid cells surrouding normal mucosal glands (A: hematoxylin and eosin staining, $\times 100)$. CD20 stain reveals diffuse, strong positivity in tumor cells (B: immunohistochemistry staining, CD20, $\times 100)$. 

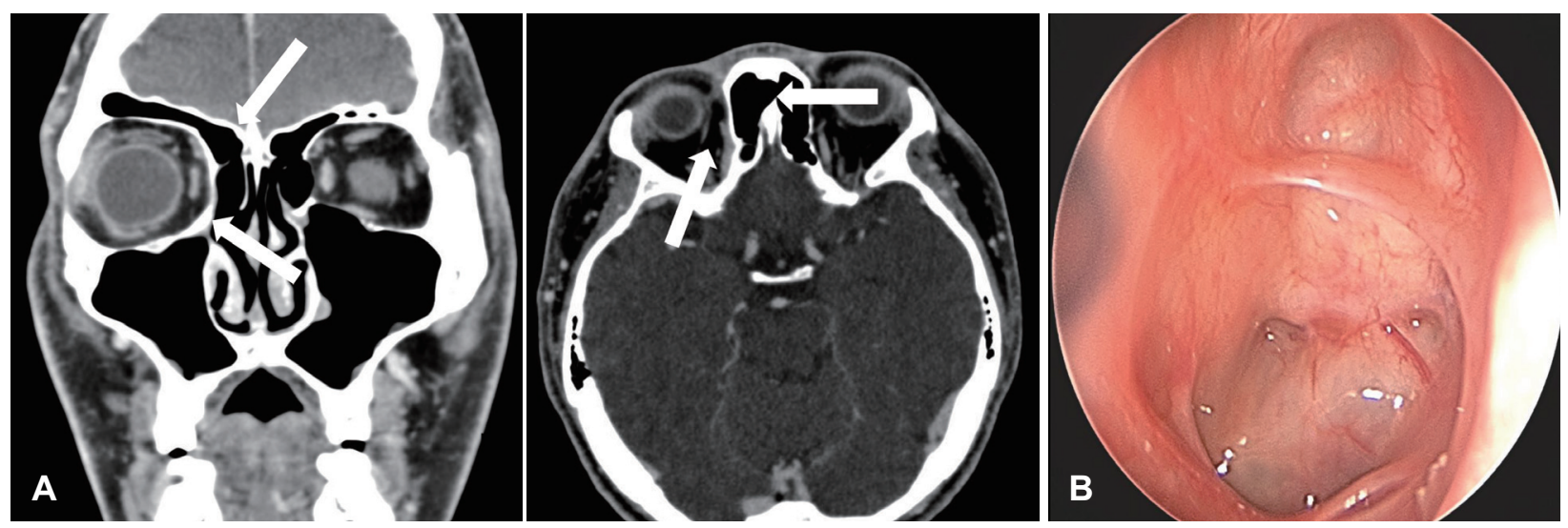

Fig. 5. Post-treatment findings ( 16 months after radiation therapy). Paranasal computed tomography (contrast) coronal and axial views of lymphoma patient. The white arrows indicate improved tumorous lesion right nasal cavity and orbit cavity (A). Endoscopic finding of ethmoid sinus after radiation therapy showing no residual lesion $(B)$.

lymphoma, FL), MALT 림프종, 외투세포 림프종(mantle cell lymphoma, MCL) 및 림프형질세포성 림프종(lymphoplasmacytic lymphoma)이 있다. MALT 림프종의 경우 특 징적으로 구별 가능한 염색법이 없기 때문에 다른 림프종을 배제하여 진단을 하게 되는데 CLL/SLL의 경우 CD5, CD23 양성, MCL의 경우 $\mathrm{CD} 5$ 과 cyclin D1 양성, $\mathrm{FL}$ 은 Bcl-6 또는 $\mathrm{CD} 10$ 양성 소견을 보여 각각을 배제할 수 있었으며 최종적 으로 MALT 림프종으로 진단하였다.

Zucca 등ㄱㅇㅣ International Extranodal Lymphoma Study Group에서 시행한 후향적 연구에서는 일반적인 비위성(nongastric) MALT 림프종의 특성상 점막에 국한되는 특징으로 인하여 주변 장기 침범이 적어 1 기 진단이 $64 \%$ 에 달한다. 다 만 4 기로 진단되는 경우도 $27 \%$ 에 달하기 때문에 본 환자 증 례와 같이 원발 부위의 영상학적 검사 외에 혈액검사와 PET$\mathrm{CT}$ 검사 및 골수검사가 필수적이다. 1 2기의 경우 5년 생존 률은 $100 \%$ 에 달하며 점막에만 국한된 경우 4기로 진단되더 라도 5년 생존률이 90\%에 달한다. National Comprehensive Cancer Network guideline에 따르면 비위성 MALT 림 프종의 1 2기의 경우 단독 방사선 요법이 선호되며 원발 부 위가 명확한 경우 수술적 치료 또한 고려할 수 있고 일부 경 우의 경우 항암화학요법 혹은 경과 관찰을 시행할 수 있으며 3 4기의 경우 항암화학요법을 시행한다. ${ }^{8)}$ 비강 혹은 부비동 내의 MALT 림프종의 경우 국내외의 명확한 치료 원칙은 없 으며 현재까지 밝혀진 다기관 연구는 없으나 앞서 언급한 국 내의 증례 3예의 경우 모두 방사선 단독 요법을 시행하였다. 최근 Lee 등이이 안구부속기에 발생한 MALT 림프종에 대한 9개의 국내 다기관 연구상 $88.9 \%$ 의 환자에서 방사선 치료 단독 요법을 시행하였음을 보고하였다.

본 증례에서는 사골동 및 안와 내에 국한되었으며 제거가 가 능한 범위의 수술적 제거 후 잔존암에 대한치료적 방사선 요
법을 시행하여 지금까지 재발 없이 좋은 치료 결과를 얻었다. 다만 장기간 완전 관해 확인을 위해 좀 더 추가적인 경과 관찰 이 필요할 것으로 사료된다.

MALT 림프종의 경우 최근 세균감염으로 인한 만성 염증 으로부터 비롯한 림프구 증식성 종물로 위장(helicobacter pylori, 이하 연관된 세균)의 경우 항생제와 위산억제제를 이 용한 제균요법으로 MALT 림프종의 유병률 감소에 대한 보 고가 있었으몀) 이 외에도 피부(borrelia burgdorferi), ${ }^{11)}$ 안구 부속기관(chlamydophila psittaci), ${ }^{12}$ 소장(campylobacter jejuni) $)^{13)}$ 및 폐(achromobacter xylosoxidans) ${ }^{14)}$ 등 타 기관 에 대한 항생제 치료를 통한 관해요법에 대하여 보고된 바가 있으나 본 증례의 조직검사상 세균집락(bacterial colony)의 증거는 발견되지 않았다.

결론적으로 저자 등은 사골동 및 안와에 발생한 MALT 림 프종 1예를 경험하였으며 병변이 주변 장기를 침범하지만 원 발부위 전이 없이 국한된 병소의 경우 부분적 수술 후 치료적 방사선 요법을 통해 좋은 치료 결과를 얻을 수 있었다. ${ }^{8}$

\section{Acknowledgments}

None.

\section{Author Contribution}

Conceptualization: Hyung-Ju Cho, Young Woo Lee. Data curation: Young Woo Lee, Hyung-Ju Cho. Formal analysis: Young Woo Lee, Young Min Moon. Funding acquisition: Hyung-Ju Cho. Investigation: Young Woo Lee, Young Min Moon, Seok Joo Lee. Methodology: Young Woo Lee, Seok Joo Lee. Project administration: HyungJu Cho. Resources: Hyung-Ju Cho, Seok Joo Lee. Supervision: HyungJu Cho. Validation: Hyung-Ju Cho, Seok Joo Lee. Visualization: Young Woo Lee, Young Min Moon, Seok Joo Lee. Writing — original draft: Young Woo Lee. Writing - review \& editing: Young Woo Lee, Young Min Moon, Hyung-Ju Cho.

\section{ORCID}

Hyung-Ju Cho 


\section{REFERENCES}

1) Quraishi MS, Bessell EM, Clark D, Jones NS, Bradley PJ. NonHodgkin's lymphoma of the sinonasal tract. Laryngoscope 2000; 110(9):1489-92.

2) Shin MS, Lim SC. Mucosa-associated lymphoid tissue lymphoma arising from the nasal mucosa: A case report and review of the literature. Korean J Otorhinolaryngol-Head Neck Surg 2006;49(12): 1227-30.

3) Kim YJ, Jeong JH, Cho SH, Kim KR, Oh YH. Two cases of mucosaassociated lymphoid tissue lymphoma of the inferior turbinate. $\mathrm{J}$ Rhinol 2010;17(1):51-6.

4) Abbondanzo SL, Wenig BM. Non-Hodgkin's lymphoma of the sinonasal tract. A clinicopathologic and immunophenotypic study of 120 cases. Cancer 1995;75(6):1281-91.

5) Kim ST, Park SJ, Hong SW, Kang YK. A case of malignant lymphoma of the thyroid gland. Korean J Otorhinolaryngol-Head Neck Surg 1998;41(1):104-8.

6) Vega F, Lin P, Medeiros LJ. Extranodal lymphomas of the head and neck. Ann Diagn Pathol 2005;9(6):340-50.

7) Zucca E, Conconi A, Pedrinis E, Cortelazzo S, Motta T, Gospodarowicz MK, et al. Nongastric marginal zone B-cell lymphoma of mucosaassociated lymphoid tissue. Blood 2003;101(7):2489-95.

8) nccn.org [homepage on the Internet]. NCCN guidelines. Plymouth Meeting, PA: National Comprehensive Cancer Network [cited 2019 Mar 27]. Available from: URL: https://www.nccn.org/ professionals/physician_gls/default.aspx.
9) Lee J, Oh D, Choi BO, Eom KY, Lee JH, Kim JH, et al. Patterns of care for orbital marginal zone B-cell lymphoma of mucosa-associated lymphoid tissue in Korea throughout 2016: Results from a multicenter cross-sectional cohort study (KROG 16-19). Asia Pac J Clin Oncol 2019.

10) Luminari S, Cesaretti M, Marcheselli L, Rashid I, Madrigali S, Maiorana A, et al. Decreasing incidence of gastric MALT lymphomas in the era of anti-Helicobacter pylori interventions: Results from a population-based study on extranodal marginal zone lymphomas. Ann Oncol 2010;21(4):855-9.

11) Roggero E, Zucca E, Mainetti C, Bertoni F, Valsangiacomo C, Pedrinis E, et al. Eradication of borrelia burgdorferi infection in primary marginal zone B-cell lymphoma of the skin. Hum Pathol 2000;31(2):263-8

12) Ferreri AJ, Guidoboni M, Ponzoni M, De Conciliis C, Dell'Oro S, Fleischhauer K, et al. Evidence for an association between chlamydia psittaci and ocular adnexal lymphomas. J Natl Cancer Inst 2004;96(8): 586-94.

13) Lecuit M, Abachin E, Martin A, Poyart C, Pochart P, Suarez F, et al. Immunoproliferative small intestinal disease associated with campylobacter jejuni. N Engl J Med 2004;350(3):239-48.

14) Adam P, Czapiewski P, Colak S, Kosmidis P, Tousseyn T, Sagaert $\mathrm{X}$, et al. Prevalence of achromobacter xylosoxidans in pulmonary mucosa-associated lymphoid tissue lymphoma in different regions of Europe. Br J Haematol 2014;164(6):804-10. 